\title{
臨床経験
}

\section{“いびき”に対する柴胡桂枝湯の 治療効果}

\author{
Efficacy of Saiko-keishi-to for Snoring
}

竹迫 賢一 日吉 俊紀

Kenichi Takesako Toshiki Hiyoshi

\begin{abstract}
要旨 いびきのひどい 12 例（脳卒中 7 例を含む, 平均 53.3 歳, 男10, 女 2 例）に対するッム ラ柴胡桂枝湯エキス剤 $7.5 \mathrm{~g} /$ 日の治療効果を検討した。効果判定は第三者の観察によるが， 2 週間後にはほぼ消失 2 例 $(17 \%)$, 半減 4 例 (33\%), やや改善 5 例 $(42 \%)$, 変化なし 1 例 (8 \%) と，汪とんぞの症例に効果が認められた。また効果発現には $3 \sim 6$ 日を要し，改善点はい びきの音量の減弱であり，柴胡桂枝湯を中止すると $2 \sim 4$ 日でいびきの音量も元に戻った。 1 例での投与方法の検討では倍量の夕食前 $5.0 \mathrm{~g} 1$ 回投薬でも, 通常投薬と同等の効果が 1 週間後 判定で得られた。作用機序としては，柴胡桂枝湯にはテンカンに対する治療効果が知られてい ることから，何らかの脳神経中枢作用を介している可能性が考兄られる。

いびきの漢方療法として，柴胡桂枝湯では最初の改善報告と思われる。
\end{abstract}

\section{緒 言}

いびきとは睡眠中または昏睡中に，口蓋帆，と きには声带の振動により生じる荒い，ガラガラし た吸気性雑音1)である。その発生の背景には睡眠 中の咽頭～軟口蓋部の筋緊張の低下や，肥満，副 鼻腔炎や鼻炎等による気道や共鳴構造の変化があ り，この部位の麻痺，特に脳血管障害等ではしば しばいびきを伴うことはよく知られている。

近年，いびきは脳血管障害2)，高血圧，虚血性

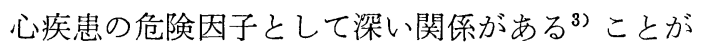
知られるようになり，またしばしば急死の原因と もなる睡眠時無呼吸症候群 ${ }^{4)}$ の 1 症状として知ら れる。ところで漢方薬は未病を防ぐとして使用さ
れることがあるが，いびきは治療対象として扱わ れず，著者らの知る限り，古典の『傷寒論』をは じめ明治時代の『勿誤薬公方函口訣』にも治療対 象として登場しない。

著者らは脳卒中に慢性 B 型肝炎を伴ら60歳男性 （症例 4 ）の肝機能異常の漢方治療に, 腹証とし て胸脇苦満と腹直筋緊張を有したため柴胡桂枝湯 エキス剤を用いたところ，いびきが著明に軽減す ることを経験した。このことから病名投与ではあ るが，いびきに対する柴胡桂枝湯の有効性につい て検討した。

\section{対象と方法}

1）柴胡桂枝湯の常用量による治療効果

医，鹿児島大学医学部りハビリテーション科，鹿児島

M. D., Department of Rehabilitation and Physical Medicine, Faculity of Medicine, Kagoshima University, Kagoshima 
表 1 柴胡桂枝湯によるいびきの治療効果

\begin{tabular}{|c|c|c|c|c|c|c|}
\hline \multirow{2}{*}{ 症例 } & \multirow{2}{*}{ 藏/性 } & \multirow{2}{*}{ 疾患 } & \multicolumn{2}{|c|}{ 効果判定 } & \multirow{2}{*}{ 効果発現日 } & \multirow{2}{*}{ 効果消失日 } \\
\hline & & & 1 週目 & 2 週目 & & \\
\hline 1) & 51男 & 脳出血 & +++ & +++ & 3 日目 & 4 日目 \\
\hline 2) & 67男 & 脳出血 & +++ & +++ & 3 & $*$ \\
\hline 3$)$ & 51男 & 脳梗塞 & ++ & ++ & 3 & $*$ \\
\hline 4) & 60男 & 脳出血 & ++ & ++ & 3 & 3 \\
\hline 5$)$ & 61女 & 脳梗塞 & ++ & ++ & 3 & $*$ \\
\hline 6) & 56男 & 脳梗塞 & + & + & 3 & 2 \\
\hline 7$)$ & 39男 & 脳出血 & $-\sim+$ & + & $*$ & 3 \\
\hline 8$)$ & 72女 & 脊䯣損傷 & ++ & ++ & 3 & 3 \\
\hline 9 ) & 27男 & 冰髄損傷 & + & + & 6 & $*$ \\
\hline 10) & 76男 & 未梢神経炎 & + & + & 3 & 2 \\
\hline 11) & 40男 & 健常人 & + & + & 4 & 2 \\
\hline 12) & 40男 & 健常人 & - & - & - & 判定不能 \\
\hline 判定基準 & \multicolumn{4}{|c|}{ 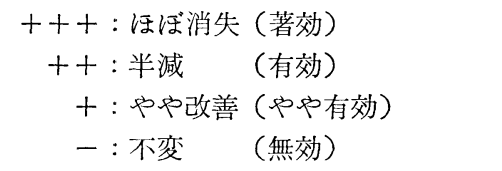 } & \multicolumn{2}{|c|}{ * 検討せず } \\
\hline
\end{tabular}

対象は当科入院のいびきのひどい10名といびき を指摘された健常人 2 名の計 12 名（男性 10 名，女 性 2 名，平均年龄53.3歳）で，最も多い基礎疾患 は脳卒中 7 例である。ッムラ柴胡桂枝湯エキス剤 は成人 1 日量（7.5g/日）を 3 回に分割投薬した。 投与方法は病名投与である。効果判定は一部の症 例を除いて毎日観察し, 最終判定は漢方投与後 2 週目に行った。判定方法は入院患者にあっては， いびきが気になる同室患者や付添い人，看護婦に よる判定とし，健常者にあってはその妻の観察に よる判定である。効果判定基準はいびきのほぼ消 失を著効, 半減を有効, やや改善をやや有効, 変 化なしを無効とした。

2 ）柴胡桂枝湯の投与方法の検討

対象は 1 例（72歳女，症例 8 ）である。投与方 法はツムラ柴胡桂枝湯エキス剤の成人 1 日量 (1) $7.5 \mathrm{~g}$, 分 3 食前投与. (通常投与法), (2) $2.5 \mathrm{~g}$, 夕 食前, (3) $5.0 \mathrm{~g}$, 分 2 朝夕食前, (4) $5.0 \mathrm{~g}, 1$ 回夕食 前の 4 つの方法を用いた。効果判定は投薬後 1 週 間目に行い, 同室患者や付添い人，看護婦の観察 そより判定した。効果判定基準は前出と同じであ る。

表 2 投与方法の違いによる効果比較

\begin{tabular}{cccc}
\hline 朝 & 昼 & 夕 & 効果判定 (1 週間後) \\
\hline 0 & 0 & $\bigcirc$ & ++ \\
& & 0 & - \\
0 & & $\bigcirc$ & $+\sim++$ \\
& & $\bigcirc$ & ++
\end{tabular}

○:ツムラ柴胡桂枝湯 $(2.5 \mathrm{~g}) 1$ 包

\section{結 果}

1）柴胡桂枝湯の常用量による治療効果 いびきに対する柴胡桂枝湯の治療効果は，表 1 の如く著効 2 名, 有効 4 名, やや有効 5 名, 無効 1名であった。著効例はいずれも脳卒中患者で, 無効例は健常人の 1 名であった。また効果発現は 投与後 $3 \sim 6$ 日目であり， 1 週目々 2 週目で大き な差はなく，少なくとも 2 週間投与であれば効果 判定は十分に可能であった。

柴胡桂枝湯の効果発現はいびきの音量の減弱と して認められたが，いびきそのものの出現頻度の 減少や持続時間の短縮などの改善には気付かなか った。またいびきは薬剤中止により $2 \sim 4$ 日目に は元の音量の状態に戻った。 
な扣，長期観察の症例 4（60歳男，脳卒中）で は，退院後も慢性肝炎のため肝機能に応じて 8 年 間にわたり柴胡桂枝湯の投薬，休薬を繰り返して いるが，いびきは投薬中には軽減し休薬中には服 薬以前と同じくらいに強くなっている。すなわち この柴胡桂枝湯のいびきに対する効果は再現性が あるものの，いびきが完全に消失することはなか った。

2 ）柴胡桂枝湯の投与方法の検討

夕食前に倍量 $(5.0 \mathrm{~g})$ のツムラ柴胡桂枝湯エキ ス剤を一度に服薬することにより，その 1 週間後 の判定では通常の 1 日 3 回服用之同等の効果が得 られた（表 2)。な和 $2.5 \mathrm{~g}$ 夕食前は効果はなかっ たが，5.0gを朝夕食前に分服した場合は常用量に 及ばないものの, やや改善〜半減の効果が得られ た。

\section{考 察}

いびきに対する柴胡桂枝湯の検討により，柴胡 桂枝はいびきに有効な漢方薬の 1 つであることが 明らかとなった。またこの方剤の特徴は，(1)効果 発現に $3 \sim 6$ 日の日数経過を要する。(2)治療効果 はいびきの音量の減弱であるが時に注ぼ消失も見 られる。(3)薬剤中止により $2 \sim 4$ 日でいびきの音 量も元に戻ることである。

漢方薬によるいびきの治験報告は，いびきを治 療すべき対象と考えなかったためと考えられる が，その治験例は極めて少ない。治療報告の多く は基礎疾患にいびきを有する 1 ～症例を対象と したもので, それには葛根湯 ${ }^{556)}$, 抑肝散加陳皮半 夏 ${ }^{7)}$, 葛根湯加川䒮辛夷桔梗黄芩 ${ }^{8)}$, 牛黄丸貼付十 鍼刺激 ${ }^{9)}$, 当帰鬚散 ${ }^{10)}$, 補中益気湯 ${ }^{11)}$, 柴胡加竜 骨牡蠇湯 ${ }^{22}$ の報告がある。柴胡桂枝湯の報告は, 著者らが知る限り今回初めての報告である。

漢方薬がどのよらな作用機序でいびきに有効で あるのかは不明な点が多いが，その背景にはいび きは治療対象となりえなかったため，いびきを漢 方的に明確に定義し説明するといった検討が充分 になされなかったことが挙げられる。㫿一昭和時 代になって中田 ${ }^{13}$ は治酒查鼻方に葛根を加兄るに あたり，その解説のなかで次のように述べてい
る。「鼻の炎症の多くに “胃熱”が関与して扣り, 胃熱は上部にある肺に燃光上がって，肺に属する 鼻に影響し，その結果，鼻づまり，いびきなどと いった症状をきたすので，葛根は胃熱を取り除く ためよく効を奏する。とくに葛根を用いなくて も, 補中益気湯, 半夏瀉心湯などといった胃を治 す処方を用いてもこういった鼻の病気が治る場合 があります。」したがっでいびきは胃熱”によっ て引き起こされる現象として説明され，治験報告 例の風邪をひき易い，鼻炎，鼻づまりといった局 所炎症の関与するものでは, 構成生薬として葛根 が重要なポイントとなっている。それ以外の葛根 を含まない補中益気湯ではいびきの改善に関し， 上気道の構成筋の弛緩といらアトニー症状の関与. するものに筋弛緩の改善作用のある補中益気湯を 用いるといら考方方 ${ }^{11}$ もあるが，中田が解説で述 べたように胃を治したために鼻（ここではいび き）が改善したと解釈することもできよう。

ところ構成生薬をみると, 柴胡桂枝湯は小柴胡 湯と桂枝湯の合方を意味する方剂で, 柴胡, 半夏, 黄芩, 甘草, 桂皮, 岁薬, 大霂, 人参, 生姜の 9 種類からなり，葛根は含まない。それぞれの生薬 の薬理活性 ${ }^{14)}$ はその活性成分之共に動物実験を通 じて検討され，明らかにされつつあるが，いびき の改善を意味する薬理作用は明らかでないことも あり, 生薬の薬理活性から説明することは困難で ある。仮説ではあるが，漢方でいう“胃熱”を除 くに注目し, 胃を改善する作用と解すれば, 柴胡 桂枝湯の構成生薬のらち抗消化性潰瘍作用のある 甘草，鎮静・鎮㽷作用のある桂枝，抗消化性潰瘍 作用のある柴胡, 鎮静 - 鎮痤・鎮痛作用や胃腸運 動促進作用, 抗胃潰瘍作用のある苟薬, 抗潰瘍作 用のある人参にその可能性がある。ただ動物実験 の薬理学的結果を臨床の場で説明するには, 人間 と動物の種特異性の問題, 同種であっても“証” の問題, 生薬成分の薬理学的血中濃度で生じる現 象が臨床的血中濃度でも生じうるか否かといった 用量の問題などをクリヤーする必要がある。

生薬の漢方的作用の解説については, 吉益東洞 の『薬徴』がよく知られているが, その薬徴解説 にはいびきや䀘の文字は見られないし，またいび 
きを意味する用語についても明らかにされていな いので，生薬といびきの関係は説明しがたい。仮 説ではあるが，もしも衝逆（体の下の方から上の 方に何かが突き上がってくるようなものと説明さ れる）がいびきと関係すると解釈するならば，柴 胡桂枝湯の構成生薬のうち甘草 ${ }^{15)}$, と桂枝 ${ }^{16)}$ が重 要な役割を演ずるし，もし奔豚（気の塊りが上の 方に突き上げることと説明される）もいびきと関 係すると解釈するならば，大東㬏有用といらこ とになる。

さらに漢方薬のもつ宿命的問題として構成生薬 を分析しても漢方方剤の本質にはたどり着けない 可能性もありらる。そのことはすでに過去の明治 11 年に男惟學が浅田宗伯の『勿䛊薬室方函口訣』18) の序文に述べており，その内容を嚙み砕いて長谷 川 ${ }^{199}$ は「処方は 1 つの絵画と同じである。原料の 色をとり出しても絵の説明にならない。薬を $1 つ$ 1 つ分析し説明しても作用はわからない。処方全 体としての組合わせの作用をみないといけない。」 と解説している。

話しは戻るが，胃熱を改善する作用以外の解釈 の可能性として, 今回報告した柴胡桂枝湯に関し

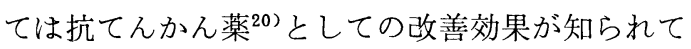
いるし, 抑肝散加陳皮半夏は神経症の適応 ${ }^{21)}$ があ り, いわゆる神経症は東洋医学では「傷気分」, 「五臓不安」,「傷蔵」に相当し, 本剂の他に柴胡 加竜骨牡蠣湯も用いられている。また柴胡加竜骨 牡蠣湯は脳内モノアミン系抑制作用:4)が知られて おり, 柴胡加竜骨牡蠣湯加味方はてんかんの治験 例22)を有しているので，これらの方剂は脳神経中 枢にも作用すると考えることができ，いびきの症 例の中には脳神経中枢性に作用し改善している可 能性が示唆される。

証は漢方薬の治療効果を高める上で大変重要な 役割を演ずる。柴胡桂枝湯においてもその臨床上 の使用目標の解説は, 慢性症については腹症とし て胸脇苦満があり，上腹部の腹直笳攣急を伴らも ので腹力は中等度ないしやや軟が典型例であると するが，大塚敬節はこれにこだわらないで使用可 と述べているといわれる23)。したがって柴胡桂枝 湯に限っては証にあまりこだわる必要はない。
最後に，いびきに対し柴胡桂枝湯が治慻効果を 示したことと，この報告はいびきに対する柴胡桂 枝湯の最初の治験報告として価值があることを強 調したい。

\section{総 括}

1）ツムラ柴胡桂枝湯エキス剤 1 日 $7.5 \mathrm{~g}$ を 2 週 間以上投与し，12例中著効 2 例を含を 11 例 (92\%) にいびきの半減〜やや改善がみられた。

2 ）効果発現は投与後 $3 \sim 6$ 日目であり，その 効果はいびきの音量の減弱であるがほぼ消失例も 見られた。

3 ）薬剤を中止すると $2 \sim 4$ 日目にいびきの音 量が元に戻った。

4 ）投与方法では 1 例経験であるが, 夜間のみ の倍量投与法は 1 日 3 回投薬と同効であった。

\section{文 献}

1 ) ステッドマン医学大辞典, 改訂第 2 版, p.1307, メジカルビュー社

2) Heikki Palomäki, et al.: Snoring as a risk factor for sleep-related brain infarction, Stroke, 20, 1311-1315, 1989

3 ) Koskenvuo, M., et al.: Snoring as a risk factor for hypertension and angina pectoris. Lancet 1, 893-896, 1985

4) 滝島 任: 睡眠時無呼吸症候群, p.1-175, 1989, 医薬ジャーナル社

5 ) 矢数道明 : <194> 小児の大いびきとストロフル 又に葛根湯，漢方治療百話(3)，p.201，1971

6 ）矢数道明 : <193> 肥厚性鼻炎による小児のいび きに葛根湯, 漢方治療百話 (3), p.200-201，1971

7 ) 矢数道明 : $\langle 60\rangle$ チック症といびきと抑肝散加陳 皮半夏, 漢方治療百話 (4), p.83, 1976

8 ) 矢数道明 : (653) 肥満少年のいびきに䓪根湯加味 方, 漢方の臨木, 35(3), p.25-27, 1988

9 ) 矢数道明 : <192> 大兵肥満男子の大いびきに天 柱刺激, 漢方治療百話 (3), p.199-200, 1971

10）矢数道明：<190>外傷後に起こったいびきに当 㱕鬚散, 漢方治療百話(3), p.198, 1971

11）川俣博嗣, 他：補中益気湯が奏功した睡眠時呼吸 障害の 1 例, 日本東洋医学会誌，42，p.457-458, 1992

12）小林英喜 : 㓷に対する柴胡加竜骨牡蛝湯エキス顆 粒の使用経験，漢方診療，11，(7)，p.10，1992 
(35)

13）中田敬吾：阿誤楽室方函口訣解説（46）治酒查鼻 方, 漢方医学講座 (25), p.50-58, 1985, 津村順天 堂

14）丁 宗鐵：漢方薬の薬理, 日医誌, 105(5), p.2032, 1992

15）大塚恭男: 薬徵解説 (5) 甘草 $1 \cdot 2$, 漠方医学講座 (16)， p.33-36，1981, 津村順天堂

16) 松下嘉一: 薬微解説 (40) 桂枝, 漢方医学講座 (19)， p.31-37，1982，津村順天堂

17) 斉藤 隆: 薬徵解説 (38) 大柬, 漢方医学講座 (19), p.19-25，1982，津村順天堂

18）男惟學: 方函口訣序, 勿誤薬室方函口訣（復刻 版), p.9, 1981, 津村順天堂

19）長谷川弥人, 他 : 勿誤薬室方函口訣解説 (1) 開講
日本東洋医学雑誌 第44卷第 1 号 (1993) 35

に亦たって，漢方医学講坐 (22), p.5-11，1983， 津村順天堂:

20）相見三郎，他：柴胡桂枝湯に上る頻癎の治療，そ の成績と考察及び脳波所見に及ぼす影響につい て, 日本東洋医学会誌，27, p.99-116, 1976

21）神庭重信, 他：神経症に対するッムラ抑肝散加陳 皮半夏の効果, 日経メディカル， 271，p.72-73， 1991

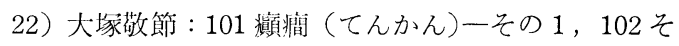
の 2,103 低血圧症を伴ら癭癎（てんかん），107， 漢方診療三十年, p.153-155，1982, 創元社

23）佐藤 弘：柴胡桂枝湯, 新版漢 J 医学, p.264265，1990，(財)日本漢方医学研究所

（1993年 1 月18日受理） 